\title{
ECAE Processed NiTi Shape Memory Alloy
}

\section{Fernanda Lídia Carvalho Lucas, Vanessa Guido, Karine Andrea Käfer}

\author{
Heide Heloise Bernardi ${ }^{\mathrm{b}, \mathrm{*}}$, Jorge Otubo ${ }^{\mathrm{b}}$
}

\author{
${ }^{a}$ Universidade do Vale do Paraíba - UNIVAP, São José dos Campos, SP, Brasil \\ ' Instituto Tecnológico de Aeronáutica - ITA, São José dos Campos, SP, Brasil \\ ${ }^{\mathrm{c}}$ Faculdade de Tecnologia de São José dos Campos - FATEC, São José dos Campos, SP, Brasil
}

Received: June 20, 2013; Revised: January 13, 2014

\begin{abstract}
The current work evaluated the microstructures and martensitic transformation temperatures of NiTi shape memory alloy (SMA) deformed by equal channel angular extrusion (ECAE). The Ti- $55.27 \mathrm{wt} . \% \mathrm{Ni}$ alloy was processed by $1 \mathrm{ECAE}$ pass at $250^{\circ} \mathrm{C}$ using a die with an intersection angle of $120^{\circ}$. After processing, samples were annealed at $300^{\circ} \mathrm{C}, 400^{\circ} \mathrm{C}$ and $500^{\circ} \mathrm{C}$ for $1 \mathrm{~h}$ to evaluate the microstructural changes. Microstructural characterization was performed by scanning electron microscopy (SEM) equipped with an energy dispersive spectrometer (EDS) device, and Vickers hardness measurement. Martensitic transformations temperatures were analyzed by differential scanning calorimetry (DSC). Results show that the annealing treatments presented no significant change in the microstructure of the ECAE processed samples. Meanwhile, the DSC curves corresponding to the annealing treatments performed at $300{ }^{\circ} \mathrm{C}$ and $400{ }^{\circ} \mathrm{C}$ show two step martensitic transformation related to $\mathrm{B} 2 \rightarrow \mathrm{R} \rightarrow \mathrm{B} 19^{\prime}$. For the annealing at $500{ }^{\circ} \mathrm{C}$, the martensitic transformation temperatures returned to the ST condition, indicating a reduction of the processing defects.
\end{abstract}

Keywords: NiTi alloy, Shape Memory Effect, ECAE

\section{Introduction}

The Shape Memory Alloys (SMA) are materials that have capacity to recover its original shape based on reverse martensitic transformation, i.e., when the alloys are deformed in the martensitic state and subsequently heated, they recover its original shape and size through transformation of the martensite to austenite phase ${ }^{1}$. In the NiTi alloys, the shape memory effect (SME) is associated with martensitic transformation from B19' (martensite) to B2 (austenite), or two stage transformation $\mathrm{B} 2 \rightarrow \mathrm{R} \rightarrow \mathrm{B} 19^{\prime}{ }^{1,2}$. In recent years, various factors that affects the structure including: Ni content, thermo-mechanical treatment and addition of alloying elements are being investigated aiming to improve the $\mathrm{SME}^{1,2}$. For NiTi alloys, the microstructural changes interfere in martensitic transformation and consequently the SME.

Regarding thermo-mechanical processing, equalchannel angular extrusion ${ }^{3}$ has been successfully applied to modify some properties of the shape memory materials ${ }^{4-7}$. Using ECAE process ${ }^{8-16}$, some studies have been done in NiTi SMA with respect to microstructural characteristics related to the change of the direct (B2 $\rightarrow$ B19') martensitic transformation to intermediate $\mathrm{B} 2 \rightarrow \mathrm{R}$ martensitic transformation.

Nevertheless, most of the literature discusses the martensitic transformation behavior in alloys deformed by ECAE in austenitic NiTi alloys ${ }^{8,9,11,12,14-16}$ and only a few works report on the martensitic NiTi alloys ${ }^{10,13}$. The present

*e-mail: heide@ita.br paper shows the results of martensitic NiTi alloy deformed by 1 ECAE pass and a correlation between microstructure, hardness and martensitic transformations temperatures.

\section{Experimental Methods}

Ti-55.27wt.\% Ni (hereafter called Ti55Ni) used in this work was produced by vacuum induction melting (VIM) and its chemical composition is: $55.27 \mathrm{wt} . \% \mathrm{Ni}(50.04 \mathrm{at} . \% \mathrm{Ni})$; $0.06 w t . \%$ C $0.0564 w t . \% \mathrm{O}$ and Ti-balance. This material was hot swaged to $10 \mathrm{~mm}$ in diameter rod, solution treated (ST) at $850{ }^{\circ} \mathrm{C}$ for 1 hour and then water quenched. Subsequently, the sample was machined to $7 \times 7 \times 60 \mathrm{~mm}$ billet and then ECAE processed. First, the sample was coated by copper based lubricant, introduced into the channel and then taken to an environmental chamber coupled to Instron 5500R machine. The environmental chamber was heated to $250{ }^{\circ} \mathrm{C}$, and after the temperature stabilization, the bar was pressed at $10 \mathrm{~mm} / \mathrm{min}$ through the die. The pressure value to deform this sample was $14 \mathrm{kN}$. The ECAE die angle was $\phi=120^{\circ}$ and $\psi=0^{\circ}$.

The deformed samples of the Ti55Ni alloy were annealed at $300{ }^{\circ} \mathrm{C}, 400{ }^{\circ} \mathrm{C}$ and $500{ }^{\circ} \mathrm{C}$ for 1 hour and air cooled. The microstructural characterization was performed using a JEOL scanning electron microscope (SEM) equipped with an energy dispersive spectrometer (EDS) system. The thermal transformation behavior during heating and cooling was investigated using a differential scanning calorimeter NETZSCH DSC404C Pegasus, with 
liquid nitrogen cooling system. Vickers hardness test was performed using a Future-Tech FM-7000 microindenter with a load of $200 \mathrm{~g} / 15 \mathrm{~s}$, in which the results correspond to the mean of ten values taken on each specimen. The micrograph analyses and hardness measurements was performed in the cross section of the specimens in Transversal DirectionNormal Direction (TD-ND) related to extrusion direction.

\section{Results and Discussion}

As shown in Figure 1, the ECAE processing $(225 \pm 12 \mathrm{HV})$ and the subsequent annealing treatment performed at $300{ }^{\circ} \mathrm{C} / 1 \mathrm{~h}(231 \pm 10 \mathrm{HV})$ resulted in a slight increase of the hardness values when compared to the ST sample (221 $\pm 26 \mathrm{HV}$ ) based on the average hardness values. As can be observed, the large distance error bar for ST condition can be attributed to the microstructure due to small precipitates. According to hardness measurements in the ST condition, the average diagonal of the indentation was $1.3 \mu \mathrm{m}$, therefore, maximum value (247 HV) corresponds

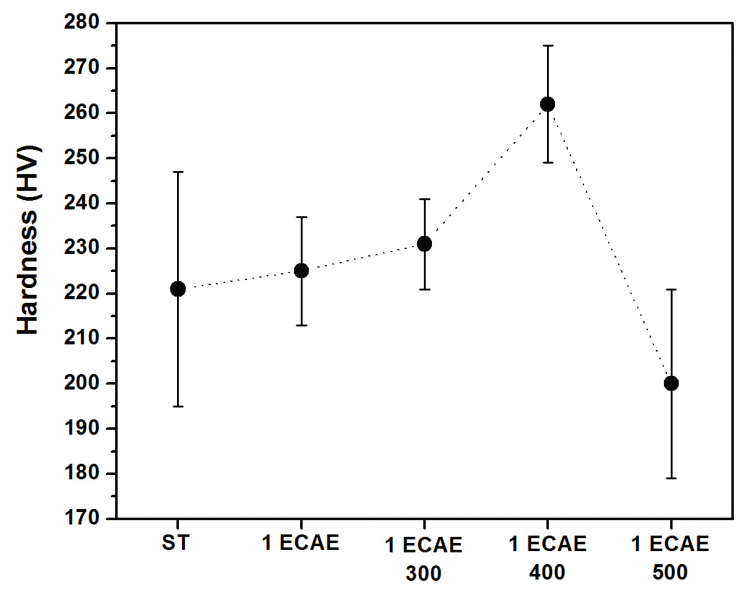

Figure 1. Hardness values of solution treated (ST), deformed (1 ECAE) and annealed samples at $300{ }^{\circ} \mathrm{C} / 1 \mathrm{~h}$ (1 ECAE 300), $400{ }^{\circ} \mathrm{C} / 1 \mathrm{~h}$ (1 ECAE 400) and $500{ }^{\circ} \mathrm{C} / 1 \mathrm{~h}$ (1 ECAE 500).

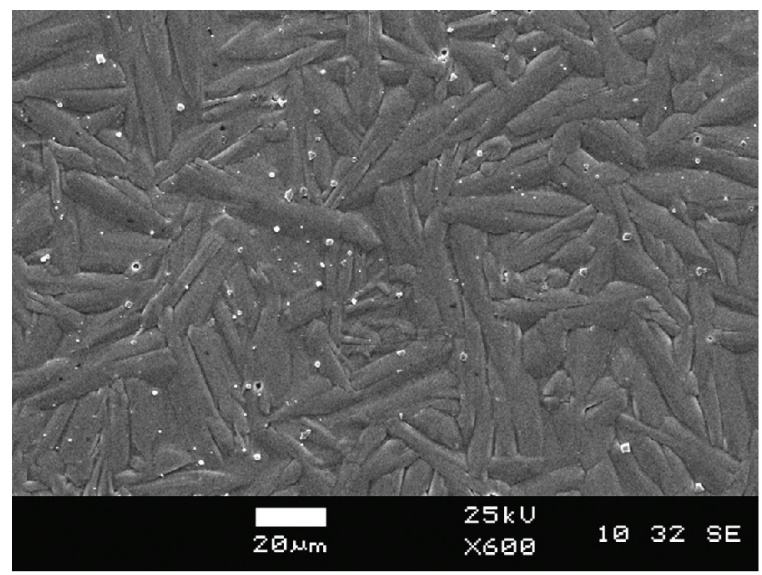

(a) to regions rich in small precipitates that was observe in the microstructure (Figures 2, 3 and 4), whose size is about $5 \mu \mathrm{m}$. Consequently, some measurement (micro indentations) could have been near these precipitates. On the other hand, minimum value (195 HV) corresponds to regions with any precipitation. Finally, some measurements (indentations) may have been over precipitates.

However, the increase of the annealing temperature to $400{ }^{\circ} \mathrm{C}$ promoted an increment in hardness values $(262 \pm 13 \mathrm{HV})$, possibly due to precipitation of $\mathrm{Ti}_{3} \mathrm{Ni}_{4}{ }^{1,2,17}$, followed by a decrease $(200 \pm 21 \mathrm{HV})$ in the further annealing treatment at $500{ }^{\circ} \mathrm{C} / 1 \mathrm{~h}$. At $400{ }^{\circ} \mathrm{C}$, the metastable phase $\mathrm{Ti}_{3} \mathrm{Ni}_{4}$ is formed in lower annealing temperature consists of thin plates coherent with the matrix increase the resistance of $\mathrm{B} 2^{2,8}$. On the other hand, at $500{ }^{\circ} \mathrm{C}$ it is also observed a variation in hardness values (large distance error bar), in this could be attributed to coarsening of the precipitates, in which maximum and minimum values corresponds at regions with or without precipitates, respectively. Furthermore, the decrease in hardness values at $500{ }^{\circ} \mathrm{C}$ could be attributed to the development of the equilibrium phase $\mathrm{TiNi}_{3}$ during the precipitation heat treatment. Transition phases are formed in a specific sequence $\mathrm{Ti}_{3} \mathrm{Ni}_{4} \rightarrow \mathrm{Ti}_{2} \mathrm{Ni}_{3} \rightarrow \mathrm{TiNi}_{3}$, in which $\mathrm{Ti}_{3} \mathrm{Ni}_{4}$ and $\mathrm{Ti}_{2} \mathrm{Ni}_{3}$ are intermediate phases, before the formation of the equilibrium $\mathrm{TiNi}_{3}{ }^{2,8}$.

The Figure 2 shows the microstructures of Ti55Ni in the ST state (Figure 2a) and deformed by 1 ECAE pass (Figure 2b). In the ST condition, the microstructure is essentially composed by martensite plates and small precipitates. After the ECAE processing, it was observed thin stress-induced martensite plates, as well as the presence of precipitates. These observations are in agreement with recent works ${ }^{14,15}$, the main significant microstructural changes produced by the first ECAE pass, like the increase of the high-angle grain boundaries, appearance of sub-grains structures, and shear bands.

The Figure 3 shows the microstructure of the Ti55Ni alloy annealed at $300{ }^{\circ} \mathrm{C}, 400{ }^{\circ} \mathrm{C}$ and $500{ }^{\circ} \mathrm{C}$. As can be observed, the annealing treatments performed up to $500^{\circ} \mathrm{C}$ presented no significant changes in the microstructure of the ECAE processed samples. According to Zhang et al. ${ }^{14}$

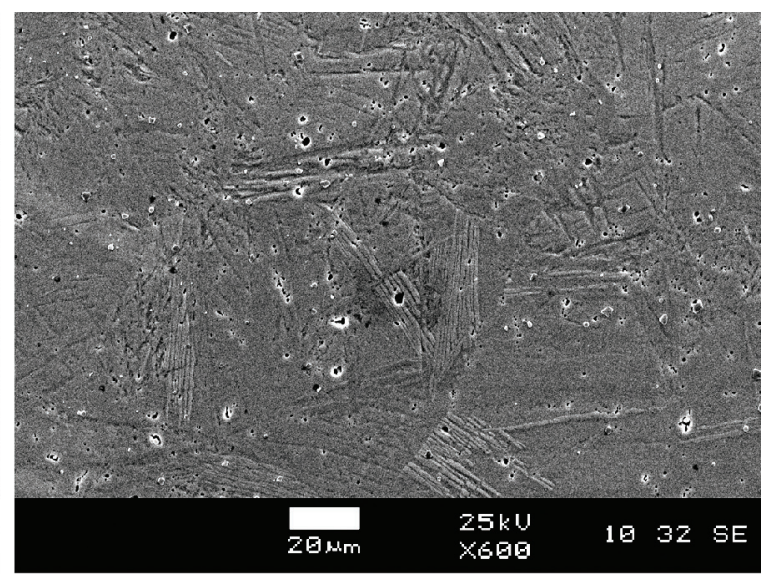

(b)

Figure 2. SEM backscattered electron images (ND-TD) of Ti55Ni alloy: (a) solution treated and (b) deformed by 1 ECAE pass. (SEM-SE). 


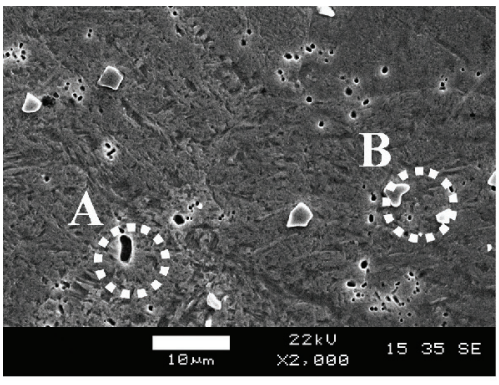

(a)

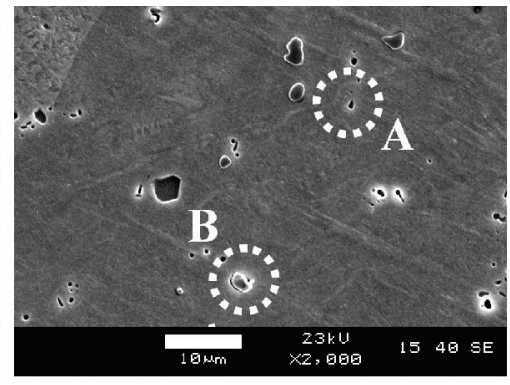

(b)

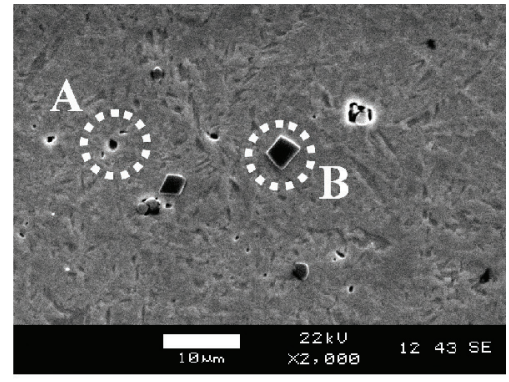

(c)

Figure 3. SEM backscattered electron images (ND-TD) of Ti55Ni alloy deformed by 1 ECAE pass and annealed at (a) $300{ }^{\circ} \mathrm{C} / 1 \mathrm{~h}$, (b) $400{ }^{\circ} \mathrm{C} / 1 \mathrm{~h}$ and (c) $500{ }^{\circ} \mathrm{C} / 1 \mathrm{~h}$. (SEM-SE).

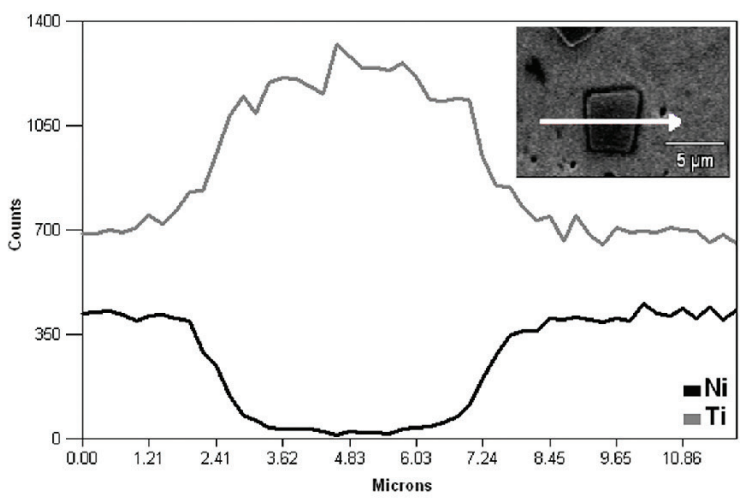

(a)

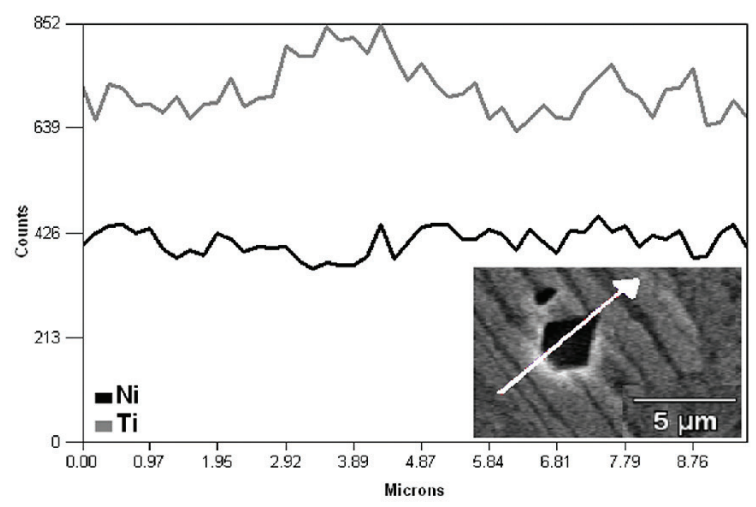

(b)

Figure 4. EDS analysis (ND-TD) of the Ti55Ni alloy deformed by 1 ECAE pass.

the recrystallization temperature for the ECAE processed austenitic NiTi alloys is higher than $500{ }^{\circ} \mathrm{C}$. Therefore, to reduce the defects introduced during the ECAE processing and refine the grain size is necessary to performed annealing treatments at higher temperatures. Compared the hardness values (Figure 1) and the annealing microstructures (Figure 3) can not attribute to annealing at $500{ }^{\circ} \mathrm{C}$ to recrystallization phenomenon, it would require annealing at high temperatures to observe the behavior of the hardness of the material, as well as changes in the microstructure.

It was observed two types of precipitates (A and B) in the Ti55Ni alloy (detached circles in the Figures 3a, b and c). This precipitates are present in the ST, deformed and annealed states, and no change in precipitates morphology was observed by increasing the heat treatment temperature.

The EDS analysis in Figure 4a revealed that one type of precipitate (B) was enriched in Ti (97wt.\%), while the other (Figure 4b) show similar composition to the surrounding matrix, with 53wt.\% Ti and 47wt.\% Ni. Probably, the Ti-rich precipitates are carbides (TiC), considering that the Ti55Ni alloy has 0.06 wt.\% C. TiC particles decrease Ti content in the matrix, therefore, decreasing the martensitic transformation peak temperature $\left(\mathrm{M}_{\mathrm{p}}\right)^{18}$. Due to the similar composition with the parent phase, it was not possible identify the precipitates of type A by the EDS analysis.
Therefore, further studies will be performed using X-ray diffraction (XRD) measurements.

The Figure 5a shows the heat flow as function as temperature curves for ST, deformed and annealed samples of the Ti55Ni alloy. During the heating and cooling cycle, the ST sample present only one endothermic and one exothermic peaks related to B19' $\leftrightarrow$ B2 martensitic transformations. The martensite start $\left(\mathrm{M}_{\mathrm{s}}\right)$ and austenite start $\left(\mathrm{A}_{\mathrm{s}}\right)$ temperatures were $29^{\circ} \mathrm{C}$ and $44^{\circ} \mathrm{C}$, respectively corroborating with the martensitic microstructure shown in Figure 2a, that is, B19' phase at room temperature. For the same martensitic transformation cycle, the martensitic transformations peak temperatures were $\mathrm{M}_{\mathrm{P}}=24{ }^{\circ} \mathrm{C}$ and $\mathrm{A}_{\mathrm{P}}=52^{\circ} \mathrm{C}$, respectively.

For the ECAE processed sample it was observed a decrease in the reverse martensitic transformation peak temperature $\left(\mathrm{A}_{\mathrm{p}}\right)$ and the appearance of two small exothermic peaks during the cooling. The first peak could be associated to $\mathrm{B} 2 \rightarrow \mathrm{R}$ transformation $\left(\mathrm{R}_{\mathrm{p}}=20^{\circ} \mathrm{C}\right)$ and the second peak to $\mathrm{R} \rightarrow \mathrm{B} 19^{\prime}$ 'transformation $\left(\mathrm{M}_{\mathrm{p}}=6{ }^{\circ} \mathrm{C}\right)$. The appearance of two peaks on cooling, was also observed for the ECAE processed samples annealed at $300{ }^{\circ} \mathrm{C} / 1 \mathrm{~h}$ and $400{ }^{\circ} \mathrm{C} / 1 \mathrm{~h}$. Especially, the annealing treatment at $400{ }^{\circ} \mathrm{C}$ resulted in two peaks in $\mathrm{R} \rightarrow \mathrm{B} 19^{\prime}$ transformation. Similar behavior was reported by Morawiec et al. ${ }^{19}$ in Ti-50.6at.\% Ni alloys coldrolled and annealed, which was attributed to inhomogeneity 


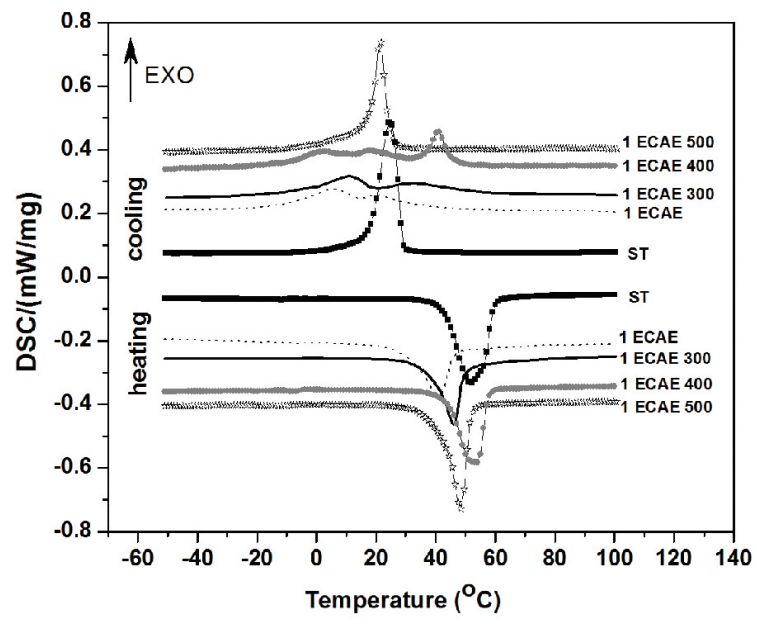

(a)

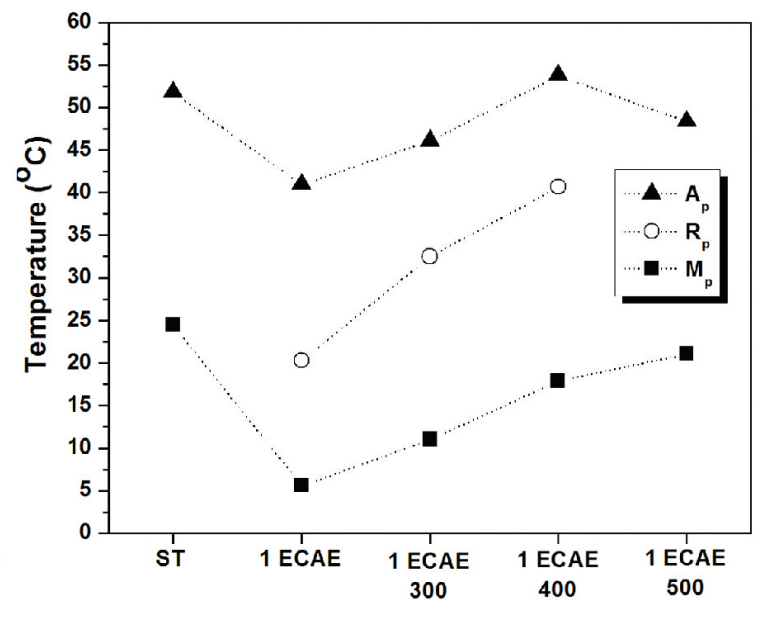

(b)

Figure 5. (a) Differential scanning calorimetry versus temperature and (b) Peak martensitic transformations temperatures $M_{p}, R_{p}$ and $A_{P}$ as a function of processing condition.

recovery process, i.e, in some regions no occur the formation of martensite, causing the occurrence of the second peak. The DSC curve corresponding to the annealing at $500{ }^{\circ} \mathrm{C} / 1 \mathrm{~h}$ presented no $\mathrm{B} 2 \rightarrow \mathrm{R}$ martensitic transformation on cooling, indicating that the effect of severe plastic deformation was eliminated at this annealing temperature. The martensitic transformation peaks temperatures in this conditions are $\mathrm{M}_{\mathrm{P}}=20^{\circ} \mathrm{C}$ and $\mathrm{A}_{\mathrm{p}}=49^{\circ} \mathrm{C}$ respectively, that is, similar to the ST condition. Figure 5b summarize the peak martensitic transformations temperatures: (a) $\mathrm{M}_{\mathrm{p}}$ (B2 $\rightarrow$ B19') in the case of ST and $1 \mathrm{ECAE}+500^{\circ} \mathrm{C} / 1 \mathrm{~h}$ samples; (b) $\mathrm{M}_{\mathrm{P}}\left(\mathrm{R} \rightarrow \mathrm{B} 19^{\prime}\right)$ and $\mathrm{R}_{\mathrm{p}}(\mathrm{B} 2 \rightarrow \mathrm{R})$ for samples $1 \mathrm{ECAE}, 1 \mathrm{ECAE}+300^{\circ} \mathrm{C} / 1 \mathrm{~h}$ and $1 \mathrm{ECAE}+400{ }^{\circ} \mathrm{C} / 1 \mathrm{~h}$ and (c) $\mathrm{A}_{\mathrm{P}}\left(\mathrm{B} 19^{\prime} \rightarrow \mathrm{B} 2\right)$ for all conditions. The $\mathrm{ST}$ state is the stable condition for martensitic transformation indicated by highest values of $M_{p}$ and $A_{p}$. The lowest values of martensitic peak transformations is for deformed state (1 ECAE) where the sample is in the state of high energy due to severe plastic deformation stabilizing the austenitic phase and promoting the appearance of R-phase. Fan et al. ${ }^{15}$ observed the same behavior for Ti-50.9at.\% Ni alloys processed with 1 ECAE pass $\left(\phi=90^{\circ}\right.$ at $\left.500^{\circ} \mathrm{C}\right)$. The annealing at $300^{\circ} \mathrm{C}$ and $400{ }^{\circ} \mathrm{C}$ increase all the transformations temperatures due to possibly two processes: dislocation recovery and precipitation of $\mathrm{Ti}_{3} \mathrm{Ni}_{4}{ }^{8,10,16,20}$. The precipitation of $\mathrm{Ti}_{3} \mathrm{Ni}_{4}$ could promote three consequences: increase the hardness (see Figure 1), promote nucleation of R-phase and increase the martensitic transformation temperatures because nickel is withdrawn from the matrix ${ }^{18}$. As stated above, the annealing at $500{ }^{\circ} \mathrm{C} / 1 \mathrm{~h}$ exhibit similar transformation behavior to the ST sample, indicating a reduction of the defects introduced during the ECAE processing.

\section{Conclusions}

The effect of ECAE processing and annealing treatments on the microstructure and martensitic transformation temperatures of a NiTi alloy was evaluated, leading to the following conclusions:

a) In the ST condition, the Ti55Ni is martensitic at room temperature as shown by microstructure and DSC measurement;

b) Based on the average hardness, the ECAE processing resulted in no significant changes of the hardness until $300{ }^{\circ} \mathrm{C}$, compared to the ST condition. For the subsequent annealing at $300{ }^{\circ} \mathrm{C}$ it was observed two step martensitic transformation related to B2 $\rightarrow$ R $\rightarrow$ B19';

c) The hardness increase after annealing at $400{ }^{\circ} \mathrm{C}$ and the presence of two peaks in the cooling is attributed to the precipitation of metastable $\mathrm{Ti}_{3} \mathrm{Ni}_{4}$ precipitate that promotes an increase in $\mathrm{M}_{\mathrm{P}}, \mathrm{A}_{\mathrm{P}}$ and $\mathrm{R}_{\mathrm{P}}$;

d) The annealing at $500{ }^{\circ} \mathrm{C}$, resulted in hardness decrease and the temperatures of martensitic transformations returning to ST condition.

\section{Acknowledgements}

Authors are thankful to FAPESP (Grants n ${ }^{\circ}$ 00/09730-1; 09/09091-3; 07/08265-2; 10/20565-4), CNPq Universal (Grant n ${ }^{\circ}$ 473612/2006-2), CNPq Casadinho - UFCG/ITA, FINEP/PRO-INFRA, Villares Metals SA, Multialloy Metais Especiais Ltda, AEB, IEAv and CNPEM/LNNano. 


\section{References}

1. Otsuka K and Wayman CM. Introduction. In. Shape Memory Materials. Cambridge University Press; 1998. p. 1-27.

2. Otsuka K and Ren X. Physical metallurgy of Ti-Ni-based shape memory alloys. Progress in Materials Science. 2005; 50(5):511678. http://dx.doi.org/10.1016/j.pmatsci.2004.10.001

3. Segal VM. Equal channel angular extrusion: from macromechanics to structure formation. Materials Science and Engineering A. 1999; 271(1-2):322-333. http://dx.doi. org/10.1016/S0921-5093(99)00248-8

4. Käfer KA, Bernardi HH, Naito LKF, Lima NB and Otubo J. Shape Memory Properties of Ultrafine-Grained Austenitic Stainless Steel. Materials Science Forum. 2013; 738-739:496500. http://dx.doi.org/10.4028/www.scientific.net/MSF.738739.496

5. Bernardi HH, Käfer KA, Naito LKF and Otubo J. Shape Recovery in Stainless FeMnSiCrNi(-Co) SMA processed by ECAE. Materials Science Forum. 2013; 738-739:252-256. http://dx.doi.org/10.4028/www.scientific.net/MSF.738739.252

6. Ma J, Karaman I, Kockar B, Maier HJ and Chumlyakov YI. Severe plastic deformation of $\mathrm{Ti}_{74} \mathrm{Nb}_{26}$ shape memory alloys. Materials Science and Engineering A. 2011; 528(25-26):76287635. http://dx.doi.org/10.1016/j.msea.2011.06.051

7. Zhang P, Ma A, Lu S, Liu G, Lin P, Jiang J et al. Effect of grain refinement on the mechanical properties of $\mathrm{Cu}-\mathrm{Al}-\mathrm{Be}-\mathrm{B}$ shape memory alloy. Materials \& Design. 2011; 32(1):348352. http://dx.doi.org/10.1016/j.matdes.2010.06.038

8. Fan $\mathrm{Z}$ and Xie C. Phase transformation behaviors of Ti-50.9 at.\% Ni alloy after equal channel angular extrusion. Materials Letters. 2008; 62(6-7):800-803. http://dx.doi.org/10.1016/j. matlet.2007.06.081

9. Pushin VG, Stolyarov VV and Valiev, RZ. Features of structure and phase transformations in shape memory TiNi-based alloys after severe plastic deformation. Annales de Chimie Science des Matériaux. 2002; 27(3):77-88.

10. Li Z, Cheng X and Shang Guan Q. Effects of heat treatment and ECAE process on transformation behaviors of TiNi shape memory alloy. Materials Letters. 2005; 59(6):705-709. http:// dx.doi.org/10.1016/j.matlet.2004.08.039

11. Karaman I, Kulkarni AV and Luo ZP. Transformation behaviour and unusual twinning in a NiTi shape memory alloy ausformed using equal channel angular extrusion. Philosophical Magazine. 2005; 85(16):1729-1745. http:// dx.doi.org/10.1080/14786430412331331961
12. Kocich R, Kursa M, Szurman I and Dlouhý A. The influence of imposed strain on the development of microstructure and transformation characteristics of Ni-Ti shape memory alloys. Journal of Alloys and Compounds. 2011; 509(6):2716-2722. http://dx.doi.org/10.1016/j.jallcom.2010.12.003

13. Karaman I, Ersin Karaca H, Maier HJ and Luo ZP. The effect of severe marforming on shape memory characteristics of a Ti-Rich NiTi alloy processed using equal channel angular extrusion. Metallurgical and Materials Transactions A. 2003; 34:2527-2539. http://dx.doi.org/10.1007/s11661003-0012-5

14. Zhang X, Song J, Huang C, Xia B, Chen B, Sun X et al. Microstructures evolution and phase transformation behaviors of Ni-rich TiNi shape memory alloys after equal channel angular extrusion. Journal of Alloys and Compounds. 2011; 509:30063012. http://dx.doi.org/10.1016/j.jallcom.2010.11.189

15. Fan Z and Xie C. Shape memory behavior of Ti-50.9at $\%$ Ni alloy after ECAE processes. Materials Science Forum. 2007; 561565:2313-2316. http://dx.doi.org/10.4028/www.scientific.net/ MSF.561-565.2313

16. Zhang X, Xia B, Son J, Chen B, Tian X, Hao Y and Xie C. Effects of equal channel angular extrusion and aging treatment on $\mathrm{R}$ phase transformation behaviors and $\mathrm{Ti}_{3} \mathrm{Ni}_{4}$ precipitates of Ni-rich TiNi alloys. Journal of Alloys and Compounds. 2011; 509(21):6296-6301. http://dx.doi. org/10.1016/j.jallcom.2011.03.062

17. Nishida M, Wayman CM and Honma T. Precipitation processes in near-equiatomic TiNi shape memory alloys. Metallurgical Transactions A. 1986; 17:1505-1515. http://dx.doi.org/10.1007/ $\mathrm{BF} 02650086$

18. Otubo J, Rigo OD, Coelho AA, Neto CM and Mei PR. The influence of carbon and oxygen content on the martensitic transformation temperatures and enthalpies of NiTi shape memory alloy. Materials Science and Engineering A. 2008; 481482:639-642. http://dx.doi.org/10.1016/j.msea.2007.02.137

19. Morawiec H, Stróż D, Goryczka T and Chrobak D. Two-stage martensitic transformation in a deformed and annealed NiTi alloy. Scripta Materialia. 1996; 35(4):485-490. http://dx.doi. org/10.1016/1359-6462(96)00179-0

20. Kabayama LK, Rigo OD and Otubo J. Influence of thermomechanical processing on the martensitic transformation temperatures of NiTi SMA wire. Materials Science Forum, 2010; 643:43-48. http://dx.doi.org/10.4028/www. scientific.net/MSF.643.43 